\title{
Study of Genetic Parameters in Soybean Germplasm Based on Yield and Yield Contributing Traits
}

\author{
Deepak Joshi", Pushpendra, Kamendra Singh and Sneha Adhikari \\ Department of Genetics and Plant Breeding, College of Agriculture, G B Pant University of \\ Agriculture and Technology, Pantnagar- 263145 (Uttarakhand), India \\ *Corresponding author
}

\begin{abstract}
A B S T R A C T
The present study was carried out at N E Borlaug Crop Research Center, G B Pant University of Agriculture and Technology Pantnagar, Uttarakhand to estimate the genetic parameters such as genotypic coefficient of variance $(\mathrm{GCV})$, phenotypic coefficient of variance (PCV), heritability $\left(\mathrm{h}^{2}\right)$ and genetic advance as percent of mean (GAM) for 12 quantitative traits of soybean (Glycine max L). Experimental material of the investigation comprised of 120 genotypes along with 5 checks. During analysis of variance, days to $50 \%$ flowering, number of nodes per plant, number of pod clusters per plant, and 100 seed weight showed highly significant difference among check varieties. The PCV and GCV values ranged between $40.33 \%$ and $30.07 \%$ for number of branches per plant and $5.34 \%$ and $5.05 \%$ for days to maturity respectively. Highest heritability was observed for 100 seed weight (99\%) and lowest heritability was observed for harvest index (22.6\%). Expected genetic advance as percent of mean ranged from 88.63 (number of nodes per plant) to 5.12 (harvest index $\%)$. High heritability coupled with high genetic advance as percent of mean was observed for days to $50 \%$ flowering, plant height, number of branches per plant, number of nodes per plant, number of pod clusters per plant, number of pods per plant, 100 seed weight, dry matter weight per plant, seed yield per plant. It can be concluded that these characters may be used as selection tool in future breeding programs.
\end{abstract}

\begin{tabular}{|l|}
\hline Ke y w or d s \\
Soybean, Genetic \\
Variability, \\
Heritability, \\
Genetic advance \\
\hline Article Info \\
\hline $\begin{array}{l}\text { Accepted: } \\
\text { 06 December } 2017 \\
\text { Available Online: } \\
\text { 10 January } 2018\end{array}$ \\
\hline
\end{tabular}

\section{Introduction}

Soybean (Glycine max L.) is considered a miracle crop due to of its extraordinary qualities. It is grown in East and South East Asia mainly for food, feed and medicinal purposes. This plant contains about $37-42 \%$ of high quality protein, 6\% ash, 29\% carbohydrate and 17 to $24 \%$ oil, comprising $85 \%$ poly unsaturated fatty acids with two essential fatty acids (lenoleic and linolenic acid) (Balasubramaniyan and Palaniappan, 2003). Soybean $(2 \mathrm{n}=40)$ belongs to Fabaceae family and is believed to have originated in northeastern China and distributed in USA, Brazil, Argentina, China, India etc. Today it ranks first in oil seed production (contribution $58 \%$ ) followed by rapeseed, groundnut, and sunflower. In India it occupied an area of 10.97 mha with the production of $11.49 \mathrm{mt}$ and productivity of $1047 \mathrm{~kg} \mathrm{ha}^{-1}$ (SOPA Databank, 2016). In India, major soybean 
producing states are Madhya Pradesh, Maharashtra, Rajasthan, Karnataka, Gujarat, Andhra Pradesh Uttar Pradesh and Chhattisgarh. The continuous improvement of soybean depends on the information about genetic variability, genetic parameters and their application, that assists the breeders in reliable selection process. Important genetic parameters include heritability, and genetic advance that enable the plant breeders to select the best breeding strategy. In this study was designed to estimate genotypic coefficient of variance (GCV), phenotypic coefficient of variance $(\mathrm{PCV})$, heritability $\left(\mathrm{h}^{2}\right)$, expected genetic advance (GA) and genetic advance as percent of mean (GAM) for yield and morphological traits of soybean that may be used as selection tools in future breeding programs.

\section{Materials and Methods}

The experiment was conducted during kharif 2014 at N E Borlaug Crop Research Centre, G B Pant University of Agriculture and Technology Pantnagar, Uttarakhand. Experimental material of the investigation comprised of 120 genotypes along with 5 checks viz., SL 688, PS 1347, PS 1092, Bragg, PS 1042. The experiment was conducted in augmented design with four blocks. Each block planted with 30 genotypes and five checks. Each accession planted in a single row of $4 \mathrm{~m}$ length with row to row distance $45 \mathrm{~cm}$ and plant to plant distance $5 \mathrm{~cm}$. The observations were recorded on five randomly selected competitive plants from a single row of each germplasm line for yield and yield contributing traits namely days to $50 \%$ flowering, days to maturity, plant height, number of branches per plant, number of node per plant, number of pods per plant, number of pod cluster per plant, plant population, 100 seed weight, dry matter weight per plant (g) and seed yield per plant (g). On the whole row basis the observation was recorded for days to
$50 \%$ flowering and maturity, whereas on the composite sample basis 100-seed weight, were recorded and derived character like harvest index also calculated.

\section{Statistical analysis}

An augmented design (Federer, 1956), which holds considerable promise for evaluation of large breeding materials were used. The analysis of variance for augmented design was done using the method given by Federer (1956, 1961) as described by Federer and Ragavarao (1975) and Petersen (1985).

\section{Estimation of variance components}

Genotypic and phenotypic components of variance were estimated with the help of following formulae.

\section{Genotypic Variance $\left(\sigma_{\mathrm{g}}{ }^{2}\right)=(\mathrm{VMSS}-\mathrm{EMSS})$} $\mathrm{X} \mathrm{CF}$

Phenotypic variance $\left(\sigma_{\mathrm{p}}^{2}\right)=\sigma_{\mathrm{g}}{ }^{2}+$ EMS

\section{Coefficient of variability}

Both genotypic and phenotypic Coefficient of variance was computed for each character as per method suggested by Burton and De Vane (1953).

$\operatorname{GCV}(\%)=\frac{\sigma_{\mathrm{g}}}{\overline{\mathrm{X}}} \times 100$

$\operatorname{PCV}(\%)=\frac{\sigma_{\mathrm{p}}}{\bar{X}} \times 100$

Where,

$\sigma_{\mathrm{g}}=$ genotypic standard deviation

$\sigma_{\mathrm{p}}=$ phenotypic standard deviation

$\bar{X}=$ grand mean of the character 


\section{Heritability $\left(\mathbf{h}^{2}\right)$}

It was estimated in broad sense by using following formula as suggested by Lush (1940).

Heritability $\left(\mathrm{h}^{2}\right)(\%)=\frac{\sigma_{\mathrm{g}}^{2}}{\sigma_{\mathrm{p}}^{2}} \times 100$

Where,

$\sigma_{\mathrm{g}}^{2}=$ Genotypic variances

$\sigma_{\mathrm{p}}^{2}=$ Phenotypic variances

\section{Genetic advance}

Genetic advance (GA) for each character was computed by adopting the formulae given by Johnson et al., (1955).

$\mathrm{GA}=\mathrm{h}^{2} \cdot \mathrm{K} \cdot \sigma_{\mathrm{p}}$

Where,

$h^{2}=$ Heritability of the character

$\mathrm{K}=$ Selection differential which is equal to 2.06 at 5 percent intensity of selection (Lush, 1949)

$\sigma_{\mathrm{p}}=$ Phenotypic standard deviation of the character

Genetic advance as per cent of mean (GAM)

$\mathrm{GAM}=\frac{\mathrm{GA}}{\overline{\mathrm{X}}} \times 100$

Where,

$\mathrm{GA}=$ Genetic advance

$\bar{X}=$ general mean of the character

The estimates of variability parameters are coefficient of variation at genotypic (GCV), phenotypic (PCV), environmental level $(\mathrm{ECV})$, heritability (\%) and genetic advance as percentage of mean. In general the estimated values of PCV were higher than GCV for all the characters studied indicating role of environment on the performance of soybean genotypes. GCV and PCV values were categorized as low (0-10\%), moderate (10$20 \%$ ) and high (20 and above) as indicated by Sivasubramanian and Menon (1973). The heritability was categorized as low $(0-30 \%)$, moderate (30-60\%) and high (60 and above) as given by Robinson et al., (1949). Genetic advance as per cent mean was categorized as low (0-10\%), moderate (10-20\%) and high (20 and above) as given by Johnson et al., (1955).

\section{Results and Discussion}

Analysis of variance for characters days to $50 \%$ flowering, number of nodes per plant, number of pod clusters per plant, and 100 seed weight showed highly significant difference among check varieties. The significant difference indicates that these traits showed significant variation with the blocks.

Significant differences among varieties were recorded for days to $50 \%$ flowering, days to maturity, plant height, number of branches per plant, number of nodes per plant, number of pod clusters per plant, number of pods per plant, and 100 seed weight (Table 1). The presence of variability gives an ample scope for improvement in population through various breeding approaches.

\section{Genotypic, phenotypic and environmental coefficient of variance (Fig. 1)}

Highest genotypic coefficient of variance was observed for number of nodes per plant (34.03) followed by number of pods per plant (33.3) and number of branches per plant (30.07). High GCV was also estimated for number of pod clusters per plant (28.72), 100seed weight (24.17) and plant height (20.67). 
Table.1 Analysis of variance (ANOVA) for yield and yield contributing traits of soybean genotypes

\begin{tabular}{|c|c|c|c|c|c|c|c|c|c|c|c|c|c|}
\hline \multirow{4}{*}{$\begin{array}{c}\text { Source } \\
\text { of } \\
\text { variation }\end{array}$} & \multirow{4}{*}{$\begin{array}{c}\text { Degree } \\
\text { of } \\
\text { freedom }\end{array}$} & \multicolumn{12}{|c|}{ MSS } \\
\hline & & \multicolumn{2}{|c|}{ Days to } & \multirow{2}{*}{$\begin{array}{l}\text { Plant } \\
\text { Height } \\
\text { (cm) }\end{array}$} & \multirow{2}{*}{$\begin{array}{c}\text { Number } \\
\text { of } \\
\text { branches } \\
\text { per } \\
\text { Plant }\end{array}$} & \multirow{2}{*}{$\begin{array}{c}\text { Number } \\
\text { of nodes } \\
\text { per } \\
\text { plant }\end{array}$} & \multirow{2}{*}{$\begin{array}{c}\text { Number } \\
\text { of pod } \\
\text { Clusters } \\
\text { per } \\
\text { Plant }\end{array}$} & \multirow{2}{*}{$\begin{array}{c}\text { Number } \\
\text { of Pods } \\
\text { per } \\
\text { Plant }\end{array}$} & \multirow{2}{*}{$\begin{array}{c}\text { Plant } \\
\text { population }\end{array}$} & \multirow{2}{*}{$\begin{array}{c}100- \\
\text { seed } \\
\text { weight } \\
(\mathrm{g})\end{array}$} & \multirow{2}{*}{$\begin{array}{c}\text { Dry } \\
\text { matter } \\
\text { weight } \\
\text { per } \\
\text { plant (g) }\end{array}$} & \multirow{2}{*}{$\begin{array}{c}\text { Harvest } \\
\text { Index } \\
(\%)\end{array}$} & \multirow{2}{*}{$\begin{array}{c}\text { Seed } \\
\text { yield per } \\
\text { plant (g) }\end{array}$} \\
\hline & & 50\%Flowering & Maturity & & & & & & & & & & \\
\hline & & 1 & 2 & 3 & 4 & 5 & 6 & 7 & 8 & 9 & 10 & 11 & 12 \\
\hline Entries & 124 & $27.76^{* *}$ & $0.22 * *$ & $354.09 * *$ & 5.14 & $280.84 * *$ & $122.83 * *$ & $865.20 * *$ & 29.78 & $3.86^{* *}$ & 79.67 & 7.98 & 8.06 \\
\hline Checks & 4 & 40.00 ** & 10 & 200.86 & 1.5 & $525.38 * *$ & $230.68 * *$ & 390.64 & 6.68 & $0.31 * *$ & 96.49 & 6.08 & 10.29 \\
\hline Varieties & 119 & $29.32 * *$ & $0.25 * *$ & $308.72 * *$ & $5.64 *$ & $329.04 * *$ & $133.02 * *$ & $929.64 * *$ & 36.45 & $3.84 * *$ & 76.32 & 8.21 & 7.8 \\
\hline $\begin{array}{c}\text { Checks } \\
\text { vs. } \\
\text { variety }\end{array}$ & 1 & -206.13 & -206.13 & 6365.98 & -40.33 & -6433.4 & -1521.5 & -4904.2 & -671.41 & 19.85 & 411.02 & -11.24 & 30.05 \\
\hline Error & 12 & 2.13 & 0.18 & 49.66 & 2.32 & 7.71 & 27.47 & 103.99 & 18.31 & 0.03 & 42.9 & 6.15 & 3.81 \\
\hline \multicolumn{14}{|c|}{ LSD at $5 \%$} \\
\hline \multicolumn{2}{|c|}{ Between checks } & 2.250462 & 2.940305 & 10.85839 & 2.347745 & 4.27782 & 8.076275 & 15.71209 & 6.59275 & 0.279944 & 10.09238 & 3.820563 & 3.006281 \\
\hline \multicolumn{2}{|c|}{ Between genotype } & 4.500923 & 5.880609 & 21.71679 & 4.69549 & 8.555639 & 16.15255 & 31.42417 & 13.1855 & 0.559887 & 20.18476 & 7.641126 & 6.012562 \\
\hline \multicolumn{2}{|c|}{$\begin{array}{l}\text { Between entries of } \\
\text { same block }\end{array}$} & 4.930514 & 6.441885 & 23.78955 & 5.143651 & 9.372233 & 17.69423 & 34.42346 & 14.44399 & 0.613326 & 22.1113 & 8.370434 & 6.586432 \\
\hline \multicolumn{2}{|c|}{$\begin{array}{l}\text { Check vs. } \\
\text { genotypes }\end{array}$} & 3.897914 & 5.092757 & 18.80729 & 4.066413 & 7.409401 & 13.98852 & 27.21413 & 11.41898 & 0.484876 & 17.48052 & 6.617409 & 5.207032 \\
\hline
\end{tabular}

* Significant at $5 \%$ level of probability, ${ }^{* *}$ Significant at $1 \%$ level of probability 
Table.2 Mean, Range, genotypic coefficient of variance (GCV), phenotypic coefficient of variance (PCV), heritability (broad sense $\mathrm{h}^{2}$ ) and genetic advance as percent of mean (GAM) for 12 quantitative traits of soybean (Glycine max L.)

\begin{tabular}{|c|c|c|c|c|c|c|c|c|c|}
\hline S. No. & Character & Mean & Range & PCV\% & GCV\% & ECV\% & $\begin{array}{c}\mathbf{h}^{2}(\mathrm{~b}) \text { in } \\
\%\end{array}$ & GA & $\begin{array}{c}\text { GA as \% } \\
\text { of mean }\end{array}$ \\
\hline 1 & Days to $50 \%$ flowering & 49.98 & $37.75-61.75$ & 10.19 & 9.759 & 2.92 & 91.8 & 12.34 & 24.68 \\
\hline 2 & Days to maturity & 110.38 & $94.8-117.8$ & 5.34 & 5.057 & 1.73 & 89.5 & 13.94 & 12.63 \\
\hline 3 & Plant height $(\mathrm{cm})$ & 72.83 & $34.8-113.54$ & 22.82 & 20.67 & 9.68 & 82 & 36.00 & 49.43 \\
\hline 4 & Number of branches per plant & 5.67 & $0.34-13.87$ & 40.33 & 30.07 & 26.89 & 55.6 & 3.35 & 59.17 \\
\hline 5 & Number of nodes per plant & 49.28 & $\begin{array}{l}18.15- \\
124.55\end{array}$ & 34.49 & 34.03 & 5.63 & 97.3 & 43.68 & 88.63 \\
\hline 6 & Number of pod clusters per plant & 33.46 & $12.25-60.45$ & 32.72 & 28.72 & 15.67 & 77.1 & 22.27 & 66.57 \\
\hline 7 & Number of Pods per plant & 80.73 & $26.6-187.4$ & 35.61 & 33.3 & 12.63 & 87.4 & 66.35 & 82.19 \\
\hline 8 & Plant population & 32.27 & $24.10-57.1$ & 18.12 & 12.35 & 13.26 & 46.4 & 7.17 & 22.21 \\
\hline 9 & 100 Seed weight $(\mathrm{g})$ & 7.56 & $2.2-12.97$ & 24.29 & 24.17 & 2.41 & 99 & 4.80 & 63.5 \\
\hline 10 & Dry matter weight per plant (g) & 37.79 & $21.22-70.04$ & 22.48 & 14.31 & 17.33 & 40.5 & 9.09 & 24.05 \\
\hline 11 & Harvest index (\%) & 32.93 & $25.93-45.65$ & 8.56 & 4.07 & 7.53 & 22.6 & 1.69 & 5.12 \\
\hline 12 & Seed yield per plant (g) & 12.39 & $8.23-22.58$ & 21.82 & 15.1 & 15.75 & 47.9 & 3.42 & 27.57 \\
\hline
\end{tabular}


Fig.1 Graphical presentation of PCV, GCV and ECV for yield and yield contributing traits of soybean genotypes

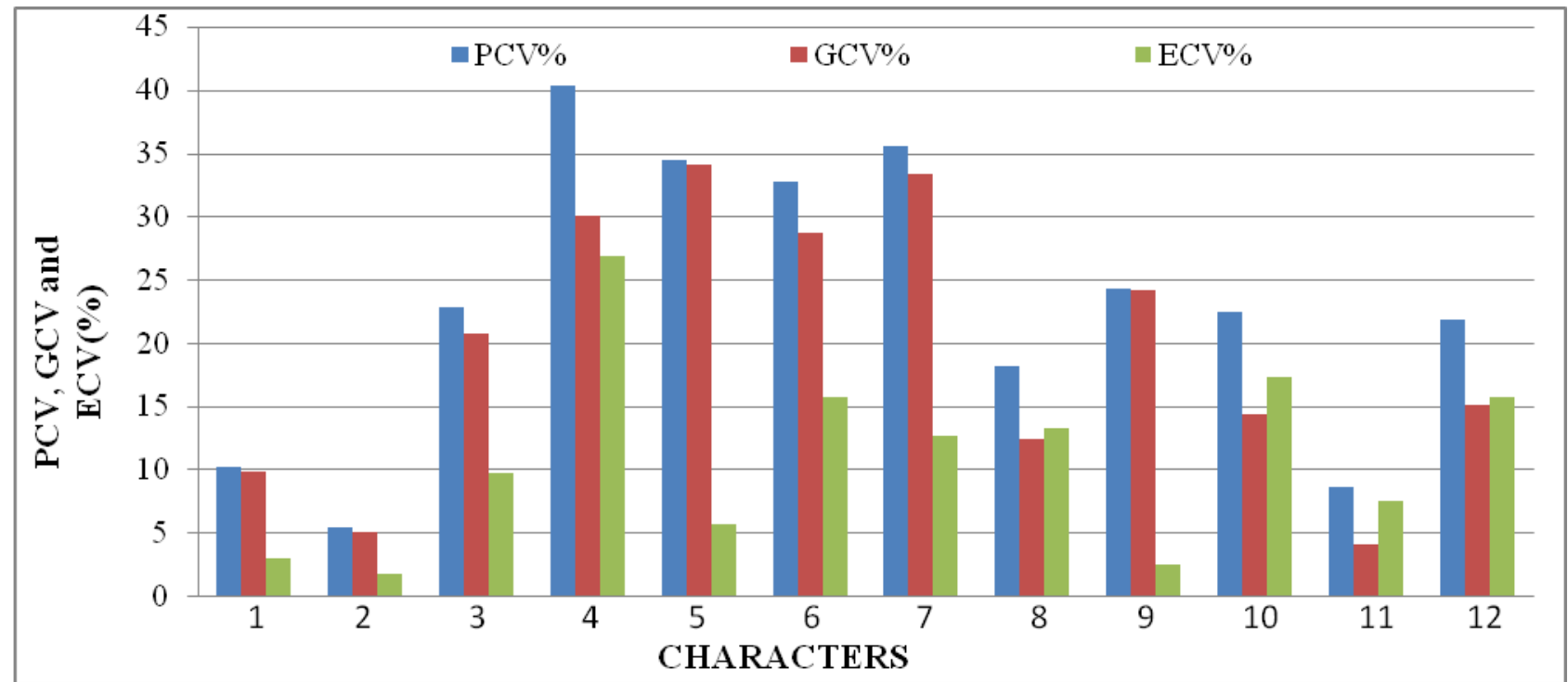

Fig.2 Graphical presentation of heritability \%, GA and Genetic Advance as \% of mean for yield and yield contributing traits of soybean genotypes

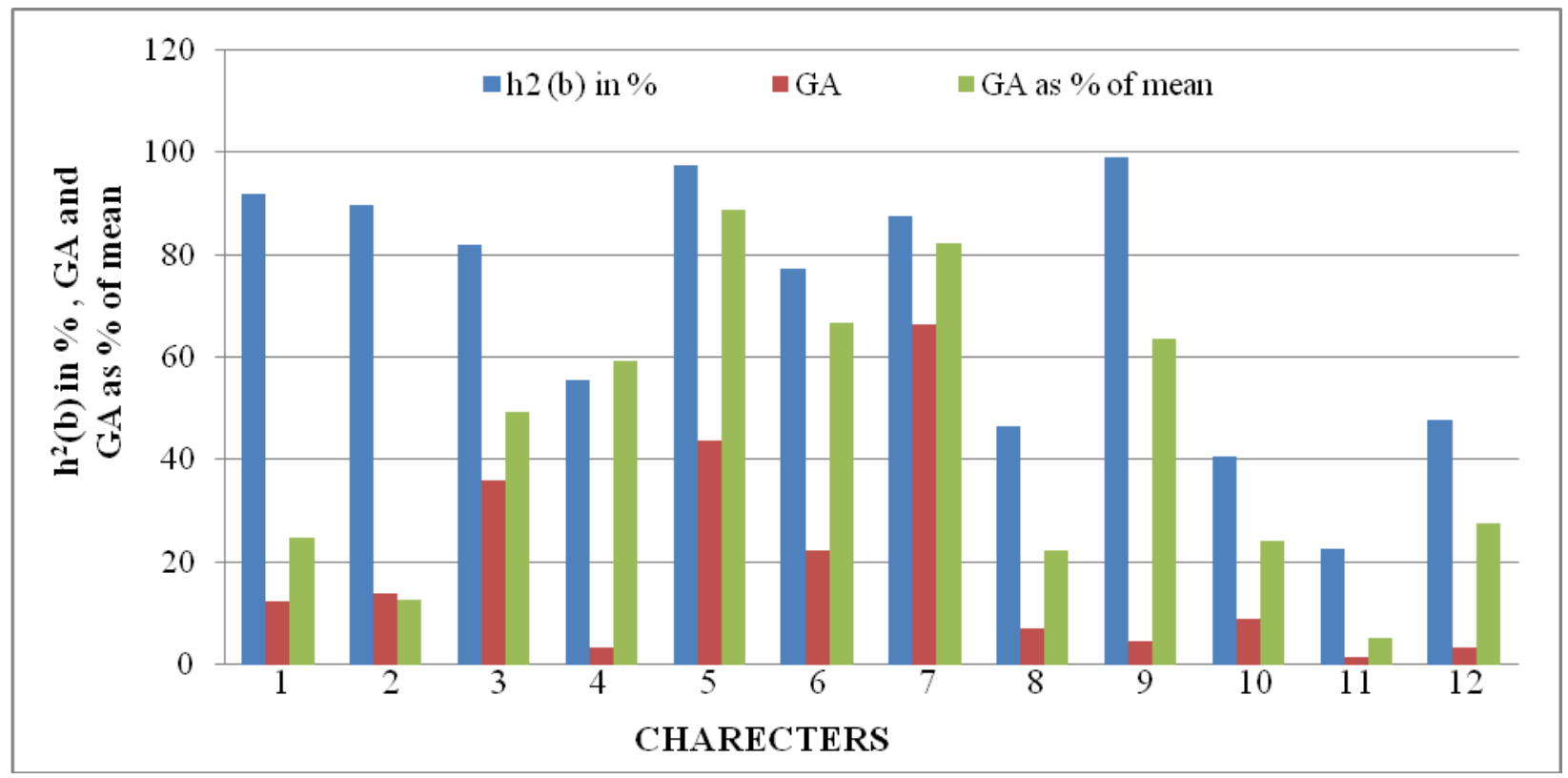

Whereas moderate GCV was recorded for seed yield per plant (g), dry matter per plant, and plant population as $15.10,14.31 \%, 12.35$ respectively, while days to flowering, days to maturity, harvest index showed low GCV as 9.75, 5.05, and 4.07 respectively. High genotypic coefficient of variation was also reported for number of branches per plant, plant height, number of pods per plant, by Rashid and Islam (1982) in fifteen varieties of soybean. They also observed low value of genotypic coefficient of variation for days to maturity. Phenotypic coefficient of variance was estimated to be highest for number of 
branches per plant (40.33) followed by number of pod per plant which was recorded as 35.61. Number of node per plant, number of pod cluster per plant, 100 seed weight, plant height, dry matter weight per plant, seed yield per plant also had high GCV as 34.49, $32.72, \quad 24.29, \quad 22.82, \quad 22.48$ and 21.82 respectively. Further moderate phenotypic coefficient of variance was noticed for plant population (18.12), days to 50 flowering (10.19), whereas harvest index (8.56) and days to maturity (5.34) showed low phenotypic coefficient of variance. The results indicated that phenotypic coefficient of variance (PCV \%) was slightly higher than that of genotypic coefficient of variance (GCV \%) for all the traits studied (Table 2). Slight differences indicated minimum environmental influence and consequently greater role of factors on the expression of the traits.

Heritability, genetic advance and genetic advance as per cent of mean (Fig. 2)

Highest heritability was observed for 100seed weight (99) followed by number of nodes per plant (97.3), days to $50 \%$ flowering (91.8), days to maturity (89.5), number of pods per plant (87.4), plant height (82), and number of pod clusters per plant (77.1).

Number of branches per plant (55.6), seed yield per plant (47.9), plant population (46.4), and dry matter weight per plant (40.5) showed moderate heritability. Pandey et al., (2010) also reported moderate heritability for seed yield per plant. Harvest index (22.6) showed low heritability, suggested that harvest index were highly influenced by environmental factors. The estimates of genetic advance expressed as per cent of mean were high for nodes per plant (88.63), pods per plant (82.19), pod cluster per plant (66.57), 100 seed weight (63.5), number of branches per plant (59.17), plant height (49.43), seed yield per plant (27.57), days to flowering (24.68), and plant population (22.21) indicating the preponderance of additive genetic effects in expression of these characters. Therefore, phenotypic selection for these characters in segregating generations would likely to be more effective. Days to maturity (12.63) showed moderate genetic advance as percent of mean, whereas harvest index (5.12) showed low GA per cent of mean.

The high value of genetic advance for these traits showed that these characters are governed by additive genes and selection will be rewarding for the further improvement of such traits. Moderate genetic advance for the traits suggest that both the additive and nonadditive variance are operating in these traits and the traits exhibiting low genetic advance indicates significance of non-additive gene effects. Heritability estimates along with genetic advance are more useful than the heritability value alone for selecting the best individual. In case of days to maturity where high heritability was coupled with moderate genetic advance as percent of mean indicating that gene governing this character is under the influence of dominant effect so one can go for the progeny test or heterosis breeding for the improvement of this character. For harvest index both heritability and genetic advance had low value that indicates high influence of environmental factor that means phenotypic selection is ineffective for this character. High heritability coupled with high genetic advance as percent of mean was observed for days to $50 \%$ flowering, plant height, number of branches per plant, number of nodes per plant, number of pod clusters per plant, number of pods per plant, 100 seed weight, dry matter weight per plant, seed yield per plant. High heritability along with high genetic advance were also recorded for number of pod per plant, plant height, and 100 seed weigh by Rajarathinam et al., (1996). Promin et al., (2014) also reported same result for pods per 
plant and seed yield per plant. Jain and Ramgiry (2000) also noticed high heritability accompanied by high genetic advance as a percentage of mean for seed yield, plant height and number of pods per plant in soybean. These result shows that seed yield can be improved by selecting simultaneously for increased plant height, number of nodes per plant, number of branches per plant, dry matter weight per plant, number of pod clusters per plant, number of pods per plant, 100-seed weight and earliness. High heritability along with high genetic advance also indicated the occurrence of additive type of gene action which provides ample scope for improvement in these traits through simple selection.

The present results indicated that the phenotypic coefficient of variability was higher than genotypic coefficient of variability for all studied characteristics. This means that these traits are less affected by the environment and are under the genetic control. Most of the studied traits revealed high heritability, expected genetic advance and genetic advance as percent of means. The characters having high heritability and high GAM may be used as selection tool in future breeding programs.

\section{References}

Balasubramaniyan, P. and Palaniappan, S. P. 2003. Principles and Practices of Agronomy, Agrbios, 45-46.

Bhairav, B., Sharma, S.P. and Ranwah, B.R. 2006. Variability, heritability and genetic advance in soybean [Glycine $\max ($ L.) Merrill]. National J. of Plant Improv. 2006; 8(1): 94-95.

Burton, G.W. and Vane, E. H. D. 1953. Estimating heritability in tall fesque (Festuca arundinacea) from replicated clonal material. Agron. J. 45: 478-481.

Chauhan, V.S. and Singh, B.B. 1983. Genetic variability and heritability in soybean. Indian J. Agric. Sci., 53 (4): 273-276.

Chettri, M., Mondal, S. and Nath, R. 2005. Studies on genetic variability in soybean, [Glycine $\max$ (L.) Merril] in the mid hills of Darjeeling District. Interacademicia. 9(2): 175-178.

Datt, S., Sharma, P.R., Kumar, M. and Gupta A. K. 2011. Genetic variability and trait relationship among yield and other quantitative traits in Soybean [Glycine $\max$ (L.) Merrill], Directorate of Research, Central Agricultural University, Imphal, Krishi Vigyan Kendr S V P U \& T Nagina, District Bijnor U.P. 24(2): 117-120.

Dixit, S.S., Pawar, K.S., Rawat, Y.S. and Singh, Jagdish. 2002. Genetic variability in soybean [(Glycine max (L.) Merrill)]. Research on Crops. 3(1): 195-196.

Ekka, N. P. and Lal, M. G. 2016. Study on genetic variability and character association in soybean [Glycine max (L.) Merrill] germplasm at vindhyan zone of Uttar Pradesh. Agric. Sci. Digest. 36 (1): 69-71.

Faisal Anwar Malik, M., Afsari, S., Qureshi, M. A., and Ghafoor, A. 2006. Genetic Variability of the Main Yield Related Characters in Soybean. Department of Biological Sciences, Quaid-I-Azam University, Islamabad-Pakistan. National Agricultural Research Centre, Islamabad-Pakistan. 8-6-815-819.

Federer, W.T. 1956. Augmented. (or Hoonuiaku) design. Hawai. Plant Rec. 55:191-208.

Ghatge, R.D. and Kadu, R.N. 1993. Genetic variability and heritability studies in soybean. Advances in Plant Sci., 6(2): 224-228.

Gohil, V.N., Pandya, H.M. and Mehta, D.R. 2006. Genetic variability for seed yield and its component traits in soybean. Agricultural Science Digest. 26(1):73- 
74.

Hakim, L., Suyamtob and Paturohman, E. 2014. Genetic variability, heritability and expected genetic advances of quantitative characters in $\mathrm{F}_{2}$ progenies of soybean crosses. Indones. J. Agric. Sci., 15(1): 1-16.

Jian, P. K. and Ramgiry, S. R. 2000. Genetic variability of metric traits in Indian germplasm of soybean (Glycine max (L.) Merrill). Adv. Pl. Sci., 13:127-131.

Johansson, A. S. 1909. Genetic variation and heritability of quantitative characters in soybean (Glycine max (L.) Merrill). Agron.J. 50(2): 270-278

Johnson, H.W., Robinson, H.F. and Comstock, R.E. 1955. Estimates of genetic and environmental variability in soyabean. Agron. J. 5: 314-318.

Joshi, A. B. and Dhawan, N. L. 1966. Genetic improvement of yield with special reference to self-fertilizing crops. Indian J. Genet. 26: 101-11.

Karad, S.R., Harer, P.N., Kadam, D.D. and Shinde, R.B. 2005. Genotypic and phenotypic variability in soybean. Journal of Maharashtra Agricultural University, 30(3): 365-367.

Karnwal, M. K. and Singh, K. 2009. Studies of genetic variability, character association and path coefficient for seed yield and its contributing traits in soybean (Glycine max (L.) Merrill). Legume Research. 32(1):70-73.

Lush, J.L. 1949. Heritability of quantitative characters of farm animals. Proc. $8^{\text {th }}$ Int. Cong. of Genet. Suppl. Vol. I. Hereditis, pp. 356-375.

Malek, M. A., Rafii, M. Y., Afroz, M. S. S., Nath, U. K. and Mondal M. M. A. 2014. Morphological Characterization and Assessment of Genetic Variability, Character Association, and Divergence in Soybean Mutants. The Scientific World Journal. Pp. 1-12.

Oliveira, D., Viana, J. M. S., Cruz, C. D. and
Sediyama, C. S. 2000. Heritability and correlation in $\mathrm{F}_{2}$ soybean plants cultivated under different environmental conditions. ActaScientiaru. 22(4): 889893.

Osekita, O. S. and Olorunfemi, O. 2014. Quantitative genetic variation, heritability and genetic advance in the segregating $\mathrm{F}_{3}$ populations in Soybean [(Glycine $\max \quad$ (L.) Merril.]. International Journal of Advanced Research. 2(7): 82-89.

Promin, L., Khoyumthem, P., Devi, N. and Paul, A. 2014. Genetic divergence studies in soybean [Glycine max (L.) Merill.]. Soybean Research (Special Issue Number 2): 75-80: 2014.

Pushpendra and Ram, H.H. 1987. Genetic components of variation for certain yield contributing traits in soybean. Indian J. Agric. Sci. 57(4): 221-224.

Rajarathinam, S., Muppidathi, N. and Pandian, R. S. 1996. Variability and character association in soybean during rabi season. Madras Agric. J. 83 (12): 776-777.

Rashid, M.H. and Islam, M.A. 1982. Coefficient of genetic variability, heritability and correlation of agronomic characters in soybean. Madras Agric. J., 69(7): 479-481.

Reni, Y. P. and Rao, K. Y. 2013. Genetic variability in Soybean [(Glycine max (L.) Merril.]. International General of Plant, Animal and Environmental Science. 3(4).

Robinson, H. F., Comstock, R. E. and Harvey, P. H. 1949. Estimates of heritability and degree of dominance in corn. Agron. J. 41:353-359.

Sharma, D., Kumar, S., Mukul, P. R. and Gupta, A. K. 2011. Genetic variability and trait relationship among Yield and other quantitative traits in Soybean [Glycine max (L.) Merrill]. Directorate of Research, Central Agricultural 
University, Imphal, Krishi Vigyan Kendra, S V P U A and T. Nagina, District Bijnor U.P. 24(2): 117-120.

Singh, A., Singh. S. K., Sirohi, A., Singh. K. V. and Kumar. R. 2004. Genetic variability, heritability and character association yield and other characters in lentil (Lens culinaris Medik). Progressive Agriculture, 8(1): 42-44 Sivasubramanian, S. and Menon, P.M. 1973. Genotypic and phenotypic variability in rice. Madras Agric. J. 60(9-13): 10931096.

\section{How to cite this article:}

Deepak Joshi, Pushpendra, Kamendra Singh and Sneha Adhikari. 2018. Study of Genetic Parameters in Soybean Germplasm Based on Yield and Yield Contributing Traits. Int.J.Curr.Microbiol.App.Sci. 7(01): 700-709. doi: https://doi.org/10.20546/ijcmas.2018.701.085 